\title{
The Effect of Zinc and Calcium Addition on Magnesium Alloy
}

\author{
Andrea Školáková1,2, Tomáš Lovaši ${ }^{1}$, Jan Pinc ${ }^{1,2}$, Zdeněk Kačenka ${ }^{1}$, Lenka Rieszováa ${ }^{1}$ Zuzana Žofková1 \\ ${ }^{1}$ Department of Metals and Corrosion Engineering, University of Chemistry and Technology, Technická 5, 16628 \\ Prague 6, Czech Republic. E-mail: skolakoa@vscht.cz \\ ${ }^{2}$ Institute of Physics, Academy of Sciences of the Czech Republic, Na Slovance 2, 18221 Prague 8, Czech Republic
}

The magnesium alloys, alloyed by the low amount of calcium and zinc concurrently, are considered as a biodegradable materials for implants. However, the as-cast alloy exhibits the insufficient mechanical properties as well as corrosion resistance which are affected mainly by the presence of brittle secondary phases, such as $\mathrm{Mg}_{2} \mathrm{Ca}$. For this reason, presented work was focused on the as-cast magnesium alloy with alloying elements ( $\mathrm{Ca}$ and $\mathrm{Zn}$ ) whose content did not exceed $1 \mathrm{wt} . \%$, specifically MgCa0.5Zn0.5 (in wt. \%). Microstructure consisted of magnesium matrix with a very low amount of $\mathrm{Mg}_{2} \mathrm{Ca}$ and $\mathrm{Ca}_{2} \mathrm{Mg}_{6} \mathrm{Zn}_{3}$ phases which crystallized along the boundaries. These phases and their localization influenced the resulted mechanical properties. The hardness was higher due to them and tensile properties were worse than the compressive ones. The addition of zinc did not improve ductility, but in the case of compressive stress-strain test, the relative deformation was satisfactory. Moreover, the corrosion resistance of as-cast alloy $\mathrm{MgCa} 0.5 \mathrm{Zn} 0.5$ was better than pure magnesium.

Keywords: Magnesium alloys, Biomaterials, Casting, Mechanical Properties, Corrosion resistance

\section{Introduction}

Magnesium based alloys are the promising materials for orthopaedic implants thank to their mechanical and osteopromotive properties [1,2], but most of them are designed mainly for automotive and aerospace applications [3]. Magnesium is generally biodegradable element with sufficient biocompatibility and mechanical characteristic where even the values of Young's modulus (41 - 45 GPa) and density $(1.7-2.0$ $\left.\mathrm{g} \cdot \mathrm{cm}^{-3}\right)$ are close to that of human bone $[1,4,5]$. Moreover, it is an essential element occurring in the human body, namely in bone tissue suggesting the stimulation of bone tissue healing when those alloys are used $[6,7]$. Biocompatibility is one of the crucial factors for biodegradable materials because the amount of released ions cannot be toxic [5]. Internal and external fixators are though usually made of stainless steel, titanium and its alloys or cobalt-chromium alloys which are with conflict of interest due to their biocompatibility, wear resistance and mechanical properties $[1,5]$. However, the use of these materials is limited. Problems lie especially in long-term applications, in stress shielding effect and moreover, the second surgery is required for removal of implants in many cases $[1,4,8]$. In contrast to mentioned alloys, magnesium-based alloys allow to avoid second surgical intervention and minimize stress shielding effect, because of their appropriate Young's modulus [4].

Despite advantages, magnesium-based alloys have been ignored for a long time due to their poor ductility at ambient temperature which is caused by the hexagonal close-packed structure. This structure has a very small number of slips systems resulting in difficult forming $[9,10]$. A further significant drawback is high corrosion rate in physiological conditions leading to the fast biodegradation and releasing of hydrogen gas forming a bubbles $[1,11]$. Bubbles are the cause of cavities in implants. On the other, reasonable corrosion rate could be utilized for the development of temporary implants. Magnesium based alloys corrode faster than pure magnesium. The explanation lies in the presence of secondary phases promoting in the micro galvanic corrosion $[1,12]$. So, magnesium matrix and precipitated phases are galvanic couples and therefore, it is necessary to refine microstructure to hamper the increasing corrosion rate. For these reasons, magnesium-based alloys are alloyed by the elements which could improve ductility in particular and increase corrosion resistance and thus, ternary systems have been investigated preferentially. Among these elements, zinc and calcium seem to be the most suitable alloying elements. The reason, why these elements are preferred, is their natural occurrence in the human body as essentials elements [3]. The released cation $\mathrm{Ca}^{2+}$ accelerates the bone growth and therefore, its presence is not harmful $[6,11,13]$. Zinc is added to improve strength at ambient temperature [3], elongation and corrosion resistance $[6,11]$ meanwhile calcium addition reduces the oxidation during heating treatment $[3,5]$. Low content of calcium refines grains sizes and weakness the texture [10]. Alloying by calcium enables to the solid solution and precipitate 
strengthening and refining of structure [5]. Strength of alloy, as well as the amount of secondary phases, increases with increasing calcium content but ductility decreases $[9,11]$. The corrosion resistance is also improved but on the contrary, formed $\mathrm{Mg}_{2} \mathrm{Ca}$ phase worsens corrosion rate $[6,14]$. This phase formed easily because its lattice has similar parameters to the lattice of magnesium [15]. Simultaneous addition of calcium and zinc to magnesium alloy leads to the formation of ternary phase $\mathrm{Ca}_{2} \mathrm{Mg}_{6} \mathrm{Zn}_{3}$ which could increase high-temperature properties [16]. On the base of the presented results, it is clear that the best combination of alloying is the addition of a low amount of zinc and calcium.

In this work, $\mathrm{MgCa0} 0.5 \mathrm{Zn} 0.5$ (in wt. \%) alloy was prepared by melting and casting. Many authors prepared magnesium alloys with the same alloying elements $(\mathrm{Ca}, \mathrm{Zn})$ and by the same technique, but their chosen chemical compositions of alloying elements usually exceed 1 wt. \% or zinc content is higher than calcium content. Microstructure, phase composition, mechanical properties and corrosion resistance were studied.

\section{Materials ans Method}

Cast $\mathrm{MgCa} 0.5 \mathrm{Zn} 0.5$ (in wt. \%) alloy was prepared by melting of pure metals in an induction furnace under $\mathrm{Ar}$ atmosphere. Commercial purity elements $(\mathrm{Mg}$, $\mathrm{Ca}, \mathrm{Zn}$ ) were used as components for the preparation in a weight ratio of 99:0.5:0.5. The melt was cast into brass molds and obtained cylindrical ingots with diameter $20 \mathrm{~mm}$ was cut transversely for analyzes.

The sample was ground using sandpapers P80P4000 and polished on diamond pastes D2. The final polishing was done on Etosil E suspension. The solution of $10 \mathrm{ml} \mathrm{HNO}_{3}, 30 \mathrm{ml} \mathrm{CH} \mathrm{CH}_{3} \mathrm{COOH}, 120 \mathrm{ml}$ $\mathrm{C}_{2} \mathrm{H}_{5} \mathrm{OH}$ and $40 \mathrm{ml} \mathrm{H}_{2} \mathrm{O}$ was used for etching. The microstructure was investigated by the optical microscope Olympus PME3 with Axion Vision 4.8 software and by scanning electron microscope Tescan Vega 3 LMU equipped with energy dispersive spectrometry OXFORD Instruments X-max EDS SDD $20 \mathrm{~mm}^{2}$ (SEM-EDS), which was applied to determine the chemical composition of phases. The phase composition was determined by X-ray diffraction (PANalytical $\mathrm{X}$ 'Pert Pro, $\mathrm{CuK} \alpha$ radiation) with PDF -2 databases.

The mechanical properties were measured as Vickers micro- (HV 0.005) and macro-hardness (HV 5) due to the heterogeneity of the samples. To characterize the mechanical behavior during loading, tensile and compressive tests were performed. Compressive and tensile tests were done using INSTRON $1362 \mathrm{ma}$ chine equipped by clip-on Instron Dynamic Extensometer. The tested samples were prepared from ascast alloy by cutting to obtain the cylinders with a height of $7.7 \mathrm{~mm}$ and a diameter of $5.4 \mathrm{~mm}$ for the compressive testing. For the tensile tests, specimens with diameter of $4 \mathrm{~mm}$ and a gauge length of $15 \mathrm{~mm}$ were prepared by a mechanical machine. Both tests were performed using three samples and according to the ASTM E9-19 (compressive test) and ASTM $\mathrm{E} 8 / \mathrm{E} 8 \mathrm{M}-16$ a standard (tensile test).

Corrosion behavior was determined using potentiodynamic curves measured in $250 \mathrm{ml}$ of physiological solution $\left(9 \mathrm{~g} \cdot \mathrm{l}^{-1} \mathrm{NaCl}\right)$. First of all, as-cast alloy (cylindrical specimen) was ground by sandpaper P2500 and subsequent, the surface was rinsed by distilled water and dried. Electrochemical measurements were carried out using potentiostat Zahner Zennium Pro and obtained data were evaluated by software Thales XT Analysis. For reproducibility, each measurement was repeated three times and a standard three-electrode set-up with $\mathrm{Ag} / \mathrm{AgCl} /$ sat. $\mathrm{KCl}$ electrode (ACLE) as a reference electrode and a graphite electrode as the counter electrode were used. The total exposed area of the studied specimen was approximately $0.8 \mathrm{~cm}^{2}$. The corrosion cell including experimental set-up is shown in Fig. 1. At first, the opencircuit potential (OCP) was stabilized for $3600 \mathrm{~s}$ with subsequent measurement of the polarization resistance. The polarization resistance was measured between $\pm 20 \mathrm{mV} / \mathrm{OCP}$ with scanning rate of $0.1 \mathrm{mV}$. $\mathrm{s}^{-1}$. After the polarization resistance, the potentiodynamic curves were measured in the range of -2 $\mathrm{V} / \mathrm{ACLE}$ to $-0.6 \mathrm{~V} / \mathrm{ACLE}$ with a scanning rate $1 \mathrm{mV}$ $\cdot \mathrm{s}^{-1}$. Tafel slopes $\beta_{\mathrm{a}}$ (anodic) and $\beta_{\mathrm{c}}$ (cathodic) were determined by extrapolation of the linear parts of potentiodynamic curves. Subsequently, the constant B could be calculated according to equation 1 . The corrosion current densities value $\left(j_{\text {corr }}\right)$ was obtained by applying equation 2 , which used constant $B$ and polarization resistance $\left(\mathrm{R}_{\mathrm{p}}\right)$.

$$
\begin{aligned}
& \mathbf{B}=\frac{\boldsymbol{\beta}_{\mathrm{a}} \cdot \boldsymbol{\beta}_{\mathrm{c}}}{2.3 \cdot\left(\boldsymbol{\beta}_{\mathrm{a}}+\boldsymbol{\beta}_{\mathbf{c}}\right)}(\mathbf{m V}), \\
& \mathbf{j}_{\text {corr }}=\frac{\mathbf{B}}{\mathbf{R}_{\mathbf{p}}}\left(\mathbf{A} \cdot \mathbf{m}^{-2}\right),
\end{aligned}
$$

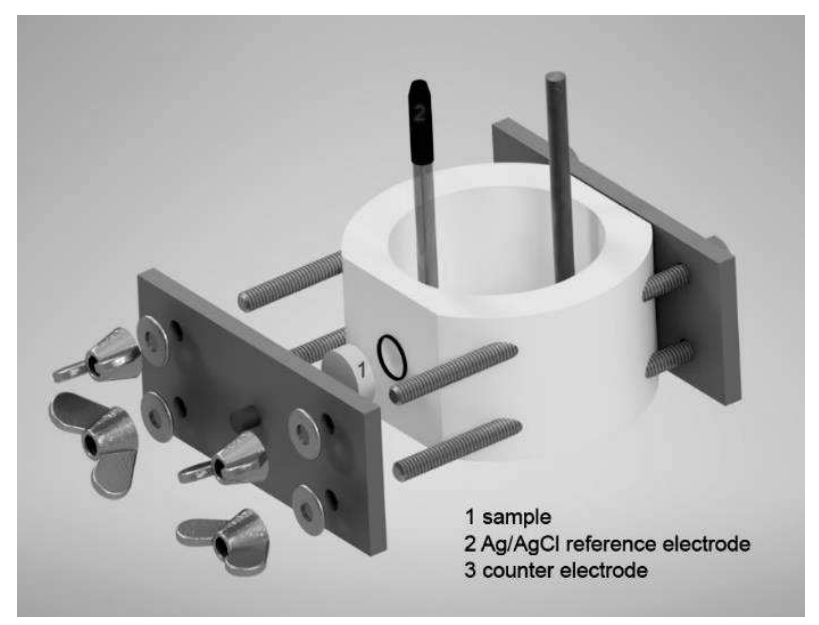

Fig. 1 Experimental set-up using for corrosion measurements 
The sample for the volumetric method was ground by sandpaper P2500. Subsequently, the sample was rinsed by ethanol, dried and hung in burette using Teflon tape. The burette was then immersed to the physiological solution $\left(9 \mathrm{~g} \cdot \mathrm{l}^{-1} \mathrm{NaCl}\right)$. Total time of volumetric method took for $5 \mathrm{~h}$ and the volume of released hydrogen was recorded every $30 \mathrm{~min}$. The volumetric method was measured only in the case of as-cast $\mathrm{MgCa} 0.5 \mathrm{Zn} 0.5$ alloy.

\section{Results}

\subsection{Microstructure of as-cast alloy}

Fig. 2a shows the optical microstructure of as-cast alloy $\mathrm{Mg}$-Ca0.5-Zn0.5 (in wt. \%) whose chemical composition was verified by XRF analysis after casting. As can be seen, there are significant boundaries and the average grain sizes exceeded $100 \mu \mathrm{m}$. It can be also observed that microstructure consisted of matrix and secondary phases which created the thin boundaries or crystallized along the boundaries (Fig. 2 b). However, these phases could not be identified even by XRD analysis and its database. XRD analysis only found the presence of magnesium and 0.5 wt. $\%$ of crystalline phase meaning the very low amount of this phase. According to diagram $\mathrm{Mg}-\mathrm{Ca}$ [17], the maximum solubility of calcium in magnesium is $0.7 \mathrm{wt} . \%$ at $516.5^{\circ} \mathrm{C}$. The obtained microstructure is not a single phase and there are precipitates evidently and therefore, it could be considered the presence of small precipitates of $\mathrm{Mg}_{2} \mathrm{Ca}$ or $\mathrm{Ca}_{2} \mathrm{Mg}_{6} \mathrm{Zn}_{3}$ eventually. Both phases are expected in obtained microstructure according to ternary diagram. Work [10] used the same content of calcium and they also could not determine the secondary phases. Finally, $\mathrm{Mg}_{2} \mathrm{Ca}$ and $\mathrm{Ca}_{2} \mathrm{Mg}_{6} \mathrm{Zn}_{3}$ phases were identified and unsolved peaks were marked (Fig. 3) after detailed analyses of minor peaks. The identified phases $\left(\mathrm{Mg}_{2} \mathrm{Ca}\right.$ and $\left.\mathrm{Ca}_{2} \mathrm{Mg}_{6} \mathrm{Zn}_{3}\right)$ corresponded to the results presented in work [6]. These phases could be observed as the white phase inner grain or at the grain boundaries in Fig. 2 b. Both phases are the typical phases arising in magnesium alloy with the addition of calcium and zinc $[9,11,18$, 19]. Their typical position of peaks with very small intensity and minor $\mathrm{X}$-ray reflections were found in our results. Weaker reflections are assumed to be hidden in background noise. It is also possible that X-ray diffraction analysis analyzed only the area inner the grain which could explain non-identification of phases. Further, EDS point analysis revealed different chemical composition of matrix and boundaries (Tab. 1) which confirms the presence of phase. Matrix consisted of mainly magnesium, labeled as primary $\alpha-M g$ phase [10], with 0.5 wt. $\%$ of oxygen but the boundaries differed in the amount of magnesium, calcium and oxygen. Although all process took under Ar atmosphere, oxygen could be present in the initial Ca powder resulting in its content in the matrix (very low content) and creating grain boundaries. On the other hand, boundaries were very thin for EDS point analysis and thus, the resulted chemical composition was affected by surrounding magnesium matrix.

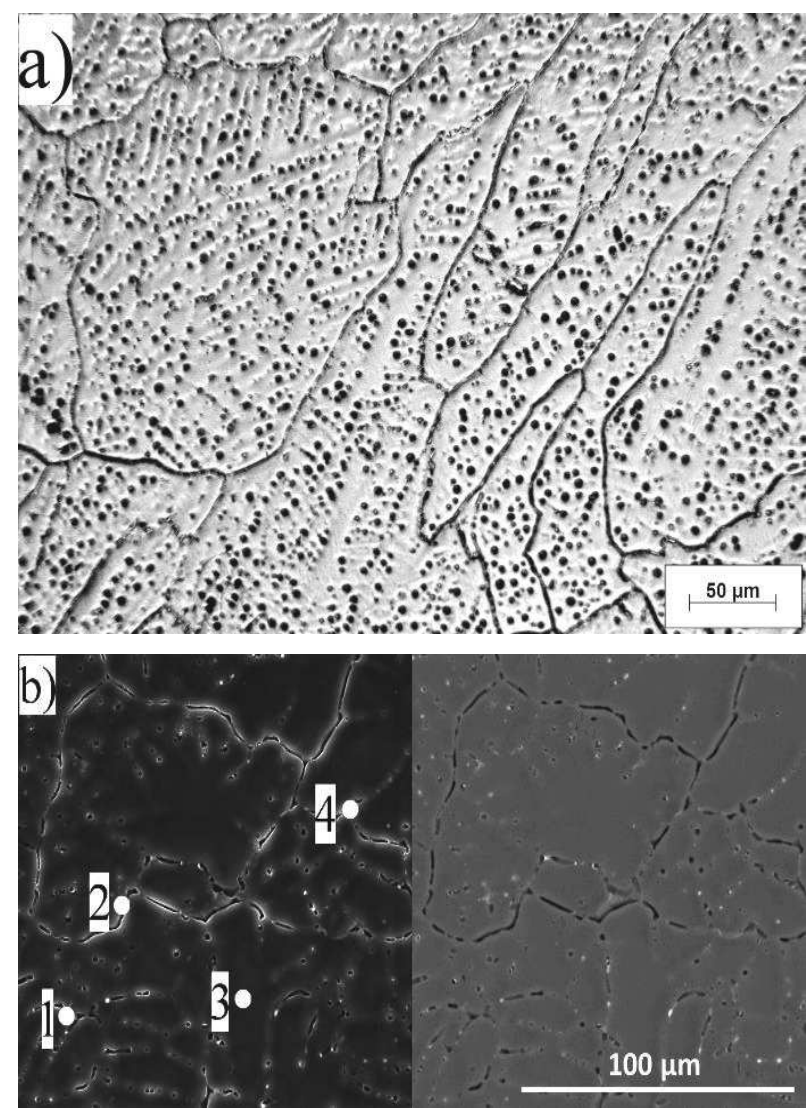

Fig. 2 Microstructure of the as-cast alloy obtained by a) light microscope; b) scanning electrone microscope

Tab. 1 Chemical composition (in wt. \%) given by the SEM +EDS point analysis of the phases

\begin{tabular}{|c|c|c|c|c|}
\hline Point & $\mathrm{Mg}$ (wt. \%) & $\mathrm{Ca}$ (wt. \%) & Zn (wt. \%) & O (wt. \%) \\
\hline 1 & $80.5 \pm 3.8$ & $3.1 \pm 3.3$ & $5.4 \pm 2.5$ & $11.0 \pm 2.0$ \\
\hline 2 & $96.3 \pm 1.7$ & $1.5 \pm 0.8$ & $1.1 \pm 0.3$ & $1.1 \pm 0.7$ \\
\hline 3 & $99.5 \pm 0.1$ & - & - & $0.5 \pm 0.1$ \\
\hline 4 & $97.4 \pm 0.6$ & $0.5 \pm 0.1$ & $1 \pm 0.4$ & $1.1 \pm 0.3$ \\
\hline
\end{tabular}




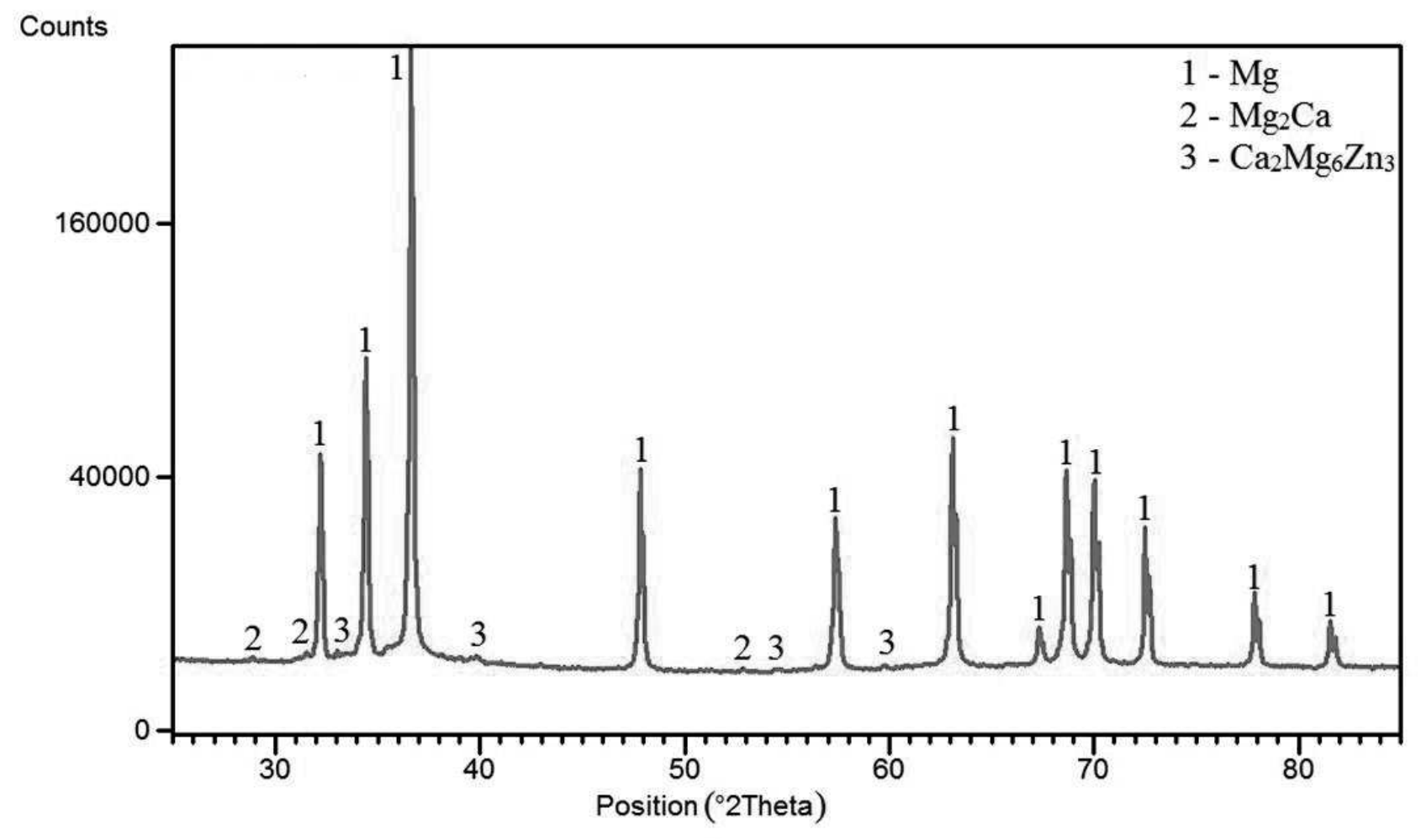

Fig. 3 XRD pattern of obtained as-cast alloy
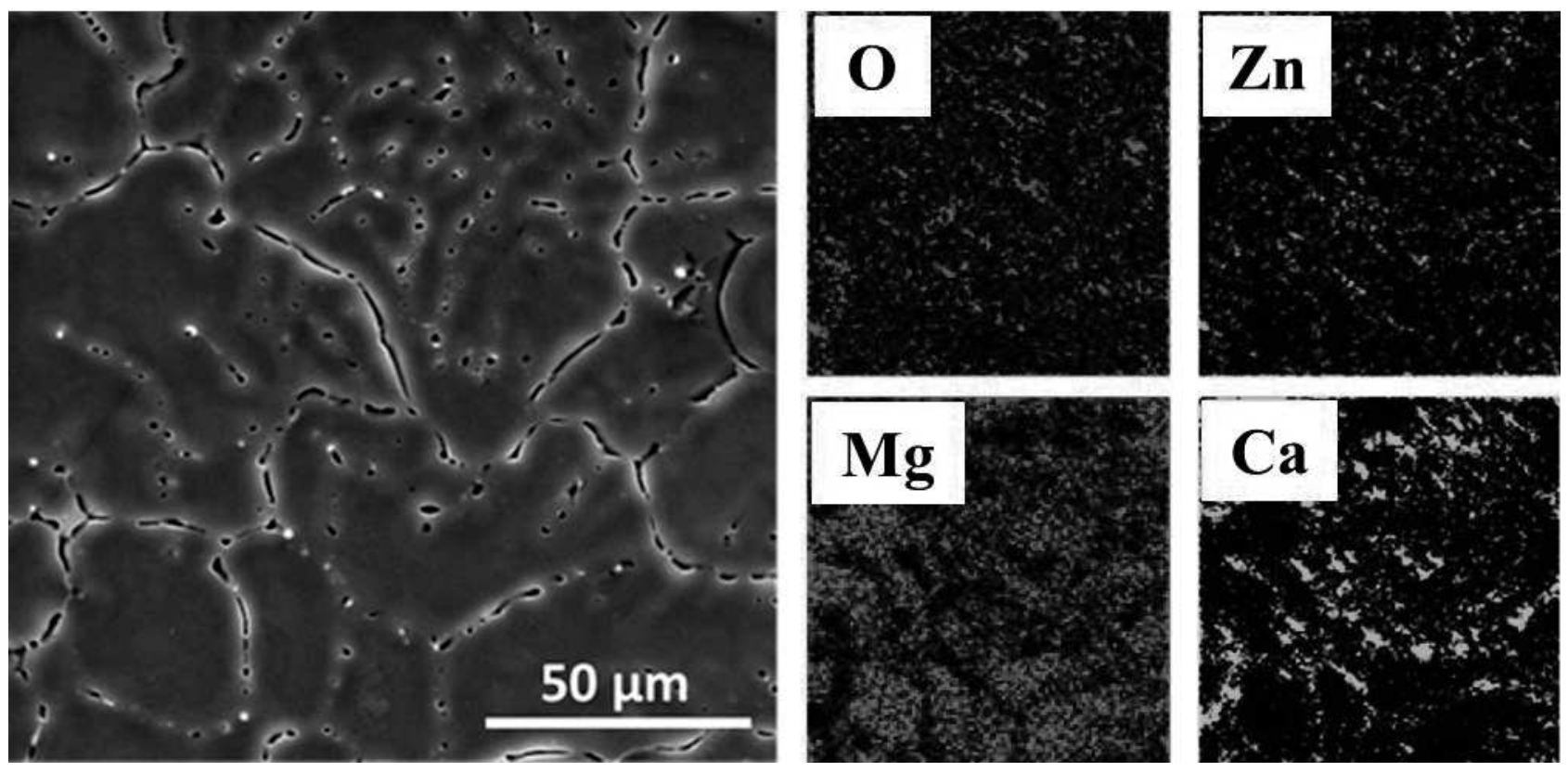

Fig. 4 The SEM + EDS element distribution maps of the as-cast alloy

Although, the present phase at grain boundaries was etched largely, element distribution maps (Fig. 4) show the increased occurrence of calcium and conversely no magnesium. Low content of oxygen was found in some places suggesting that $\mathrm{CaO}$ could form but XRD did not reveal its presence. However, when we compare the results from EDS point analysis with results from element distribution maps, it seems that oxygen is present only in etched boundaries, specifically in holes. In other words, used etching agent could remain in holes which could cause its finding in the microstructure. This fact excludes the formation of $\mathrm{CaO}$. It was found [13] that the $\mathrm{Mg}_{2} \mathrm{Ca}$ phase belongs to the typical phases precipitating along the boundaries. Therefore, it can be suggested that a very fine $\mathrm{Mg}_{2} \mathrm{Ca}$ phase was enriched by magnesium for its formation from the boundaries which became thinner. This phase contains approximately 55 wt. \% of magnesium so, part of calcium content was consumed for its formation, minor part for the formation of 
$\mathrm{Ca}_{2} \mathrm{Mg}_{6} \mathrm{Zn}_{3}$ phase and the rest of one remained at the boundaries. Further, it is necessary to realize, that XRD analysis showed only 0.5 wt. \% of crystallite phase $-\mathrm{Mg}_{2} \mathrm{Ca}$ and $\mathrm{Ca}_{2} \mathrm{Mg}_{6} \mathrm{Zn}_{3}$ resulting in small consumption of calcium. Thus, the increased amount of calcium was located at boundaries. Higher content of calcium at the boundaries can be also explained by the low solubility of magnesium as matrix [20] and $\mathrm{Mg}_{2} \mathrm{Ca}$ phase was mainly etched. In Fig. 2 b, light areas are obvious which should be confirmation of $\mathrm{Mg}_{2} \mathrm{Ca}$ phase [20]. This fact can be demonstrated only by transmission electron microscopy. Moreover, the same microstructure was observed in work [18] where they also showed the same phase composition. Small black spots locating inside the grain (Fig. 2 a) are secondary phases $\mathrm{Mg}_{2} \mathrm{Ca}$ according to works $[18,20]$ that supports uniform dispersed phases in our case. Mentioned works studied the same addition of calcium.

\subsection{Mechanical properties of as-cast alloy}

The Vickers micro- and macro- hardness were measured under load a $5-\mathrm{kg}$ and $5 \mathrm{~g}$, respectively. Results are shown in Fig. 5 and small standard deviations imply that the microstructure was homogeneous. The Vickers hardness was approximately 44 HV 5 and microhardness 29 HV 0.005. The hardness of as-cast alloy was caused by the secondary phase $-\mathrm{Mg}_{2} \mathrm{Ca}$ and $\mathrm{Ca}_{2} \mathrm{Mg}_{6} \mathrm{Zn}_{3}$ because it is known that the hardness of pure magnesium is 29 HV 5 [11]. The measured hardness was slightly higher than the hardness of binary alloy with higher amount of calcium $\mathrm{Mg}-2 \mathrm{Ca}$ [11] suggesting that $\mathrm{Ca}_{2} \mathrm{Mg}_{6} \mathrm{Zn}_{3}$ phase did not influence the hardness much. Moreover, its amount was low and thus, the effect can be negligible.

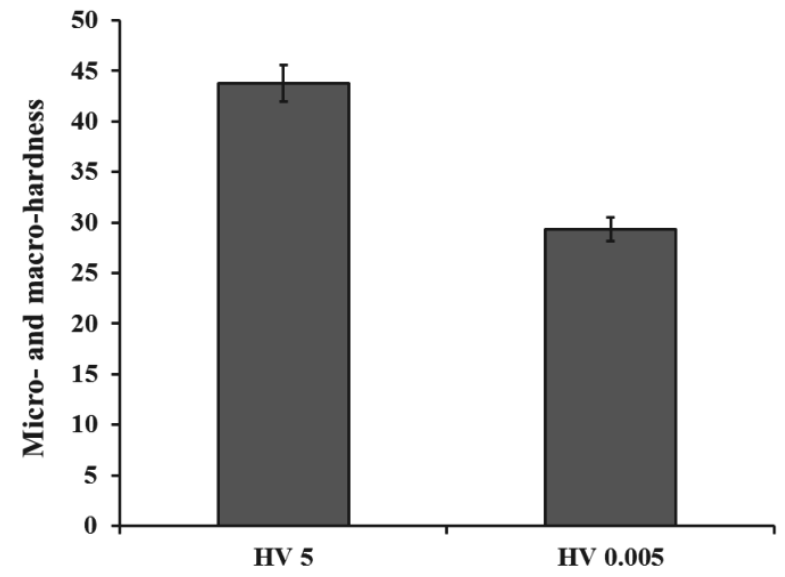

Fig. 5 Micro- and macro-hardness of the as-cast alloy

Mechanical properties are the most important aspects of bone implants. Compressive stress-strain and tensile curves are given in Fig. 6. As can be seen, tensile properties are worse than compressive ones. The average ultimate tensile strength (UTS) was $129 \pm 31$ $\mathrm{MPa}$ with yield strength (YS) $81 \pm 8 \mathrm{MPa}$ and elongation did not exceed $5 \%$. Similar results were published in work [6] where they studied magnesium alloy with 3 wt. \% of calcium. Values of compressive properties were much higher: $278 \pm 15 \mathrm{MPa}$ for compressive strength and $110 \pm 17 \mathrm{MPa}$ for YS. The relative deformation was $21 \pm 2 \%$ in this case. It is known that the ductility is worsened by $\mathrm{Mg}_{2} \mathrm{Ca}$ phase [6] which is brittle and thus harmful for mechanical properties. As it was mentioned above, $\mathrm{Mg}_{2} \mathrm{Ca}$ phase crystallized along the grain boundaries which could be the crack source. The zinc addition should improve ductility but its content was too small. Works usually studied higher additions of zinc $[6,10,21]$. This phase was not harmful during the compressive stress-strain test because the mechanical characteristics were significantly better. This means that formed cracks were healed by pressure immediately which was still repeated.

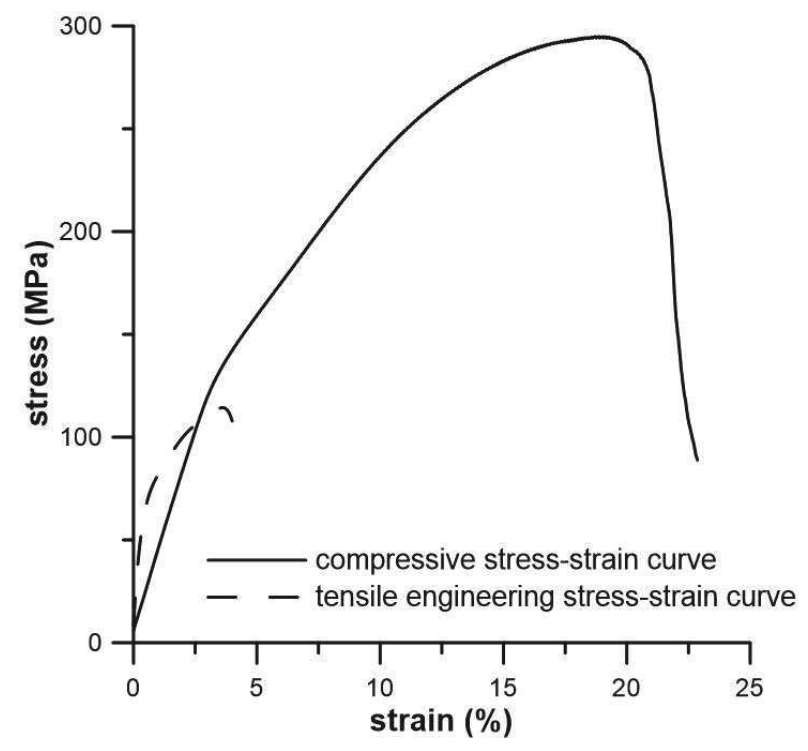

Fig. 6 Compressive stress-strain and tensile curves

\section{.3 Corrosion resistance of as-cast alloy}

The electrochemical tests were performed in physiological solution to determine the corrosion behavior of as-cast $\mathrm{MgCa0} 0.5 \mathrm{Zn} 0.5$ alloy in comparison with the corrosion behavior of pure magnesium. Although the additions of $\mathrm{Ca}$ and $\mathrm{Zn}$ were low, the changes of opencircuit potential belonging to pure $\mathrm{Mg}$ and studied ascast alloy were not so significant and different. The effect of alloying elements could be possible to observe during the measurement of polarization resistance because pure magnesium reached the lower values than as-cast alloy. The measured values are listed in Tab. 2.

Tab. 2 The values of open-circuit potential and polarization resistance

\begin{tabular}{|c|c|c|}
\hline & $\begin{array}{c}\mathrm{E}_{\text {corr }} \\
(\mathrm{mV} / \mathrm{ACLE})\end{array}$ & $\begin{array}{c}\mathrm{R}_{\mathrm{p}}(\mathrm{k} \Omega \cdot \\
\left.\mathrm{cm}^{2}\right)\end{array}$ \\
\hline Pure Mg & $-1616 \pm 28$ & $1.4 \pm 0.39$ \\
\hline $\begin{array}{c}\text { As-cast } \\
\mathrm{MgCa0} .5 \mathrm{Zn} 0.5\end{array}$ & $-1629 \pm 24$ & $1.7 \pm 0.29$ \\
\hline
\end{tabular}




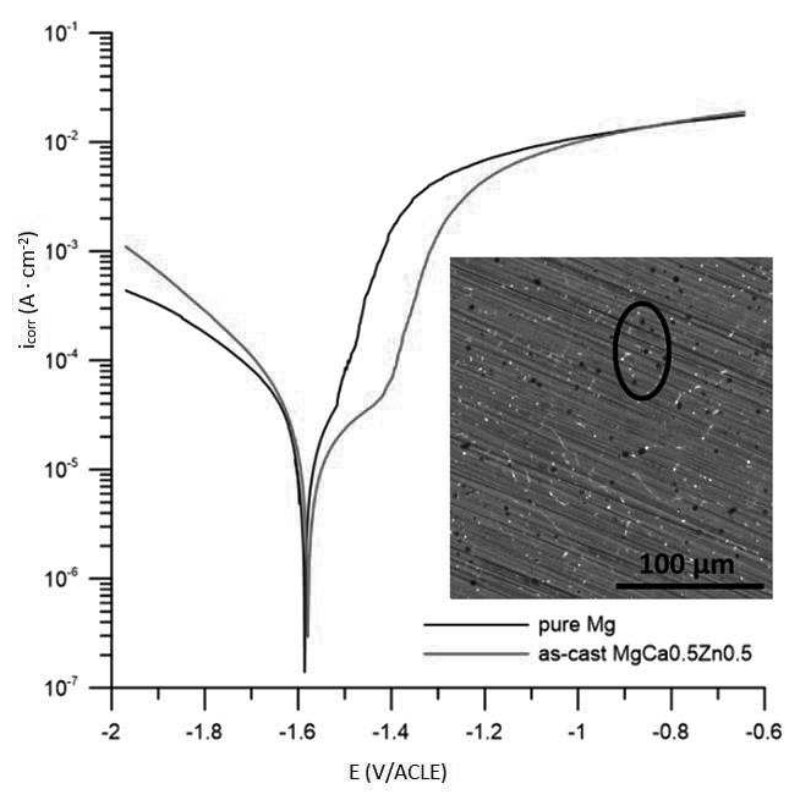

Fig. 7 Potentiodynamic curves of pure $M g$ and the as-cast $\mathrm{MgCa0} .5 \mathrm{Zn0} 0.5$ alloy tested in physiological solution at ambient temperature with detail of microstructure of as-cast alloy after exposition

Fig. 7 illustrated the potentiodynamic polarization in physiological solution. It is generally known, that the pure magnesium creates a passive layer of $\mathrm{Mg}(\mathrm{OH})_{2}$ on its surface when the pure magnesium is exposed to an aqueous electrolyte. However, the layer of $\mathrm{Mg}(\mathrm{OH})_{2}$ is porous with an insufficient protective effect. Pure magnesium is activated at higher oxidizing ability of model medium. This transition active-passive is accompanied by the formation of dimples at $\mathrm{E}$ $=-1.5 \mathrm{~V} /$ ACLE for both tested materials as can be seen in Fig. 7. In the case of as-cast alloy, the pitting corrosion arised mainly at the grain boundaries which is shown in the detail of microstructure in Fig. 7. This means that $\mathrm{Mg}_{2} \mathrm{Ca}$ phase is corroded, leaving holes on the surface. The cathodic part of the polarization curve of $\mathrm{MgCa} 0.5 \mathrm{Zn} 0.5$ exhibits the increase of rate belonging to the cathodic reaction which can be attributed to the addition of zinc [22].

On the base of these corrosion parameters, the corrosion rate could be calculated and results are shown in Tab. 3.

On the based of obtained electrochemical measurements, it is clear that the as-cast alloy $\mathrm{MgCa} 0.5 \mathrm{Zn} 0.5$ exhibits lower corrosion rates compared to pure magnesium. This fact can be attributed to the presence of secondary phases, namely $\mathrm{Mg}_{2} \mathrm{Ca}$ and $\mathrm{Ca}_{2} \mathrm{Mg}_{6} \mathrm{Zn}_{3}$. It indicates the tendency for localized corrosion. The primary $\mathrm{Mg}_{2} \mathrm{Ca}$ phase became anode in magnesium matrix while magnesium matrix became cathode. Wan et al. [23] presented the increase addition of calcium worsens corrosion resistance. In the case of the connection between $\mathrm{Mg}_{2} \mathrm{Ca}$ and $\mathrm{Ca}_{2} \mathrm{Mg}_{6} \mathrm{Zn}_{3}$ phases, $\mathrm{Ca}_{2} \mathrm{Mg}_{6} \mathrm{Zn}_{3}$ phase is cathode while $\mathrm{Mg}_{2} \mathrm{Ca}$ is an anode. This means that binary phase corrodes faster than a ternary phase and magnesium matrix in $\mathrm{MgCa} 0.5 \mathrm{Zn} 0.5$ alloy. It can be assumed, that the disappearance of $\mathrm{Mg}_{2} \mathrm{Ca}$ phase due to its corrosion can cause less activation of $\mathrm{Ca}_{2} \mathrm{Mg}_{6} \mathrm{Zn}_{3}$ phase resulting in corrosion of the magnesium matrix. This assumption was observed by Bakhsheshi et al. [19], who revealed this disappearance of $\mathrm{Mg}_{2} \mathrm{Ca}$ phase after alloying by zinc (> 3 wt. \%) and the corrosion rate was higher. This increment was described as corrosion process in close distance of $\mathrm{Ca}_{2} \mathrm{Mg}_{6} \mathrm{Zn}_{3}$ and $\alpha-\mathrm{Mg}$ phases, where the magnesium matrix corroded around the $\mathrm{Ca}_{2} \mathrm{Mg}_{6} \mathrm{Zn}_{3}$ phase. According to Cain et al. [24], the activity of a single-phase can be deduced in the following order $\mathrm{Ca}_{2} \mathrm{Mg}_{6} \mathrm{Zn}_{3}>\alpha-\mathrm{Mg}>\mathrm{Mg}_{2} \mathrm{Ca}$. Therefore, the ratio of $\mathrm{Ca} / \mathrm{Zn}$ plays an important role. However, the exact ratio has not been determined and known yet because the additions of zinc are always different. The amount of zinc is stated from 1 wt. \% [25] to 3 wt. \% [19] when the positive effect of zinc was observed. Further, high activity of $\mathrm{Mg}_{2} \mathrm{Ca}$ phase is affected by chemistry and crystal structure [14] which supported the mentioned order of activity.

Tab. 3 Electrochemical characterization parameters of tested materials determined from potentiodynamic curves

\begin{tabular}{|c|c|c|c|c|}
\hline & $\mathrm{I}_{\text {corr }}\left(\mathrm{A} \cdot \mathrm{cm}^{-2}\right)$ & $\mathrm{B}_{\mathrm{c}}\left(\mathrm{mV} \cdot \mathrm{dec}^{-1}\right)$ & $\mathrm{B}_{\mathrm{a}}\left(\mathrm{mV} \cdot \mathrm{dec}^{-1}\right)$ & $\mathrm{V}_{\text {corr }}\left(\mathrm{mm} \cdot \mathrm{year}^{-1}\right)$ \\
\hline Pure Mg & $0.29 \pm 0.04$ & $280.7 \pm 56.4$ & $167.3 \pm 64.5$ & $0.67 \pm 0.09$ \\
\hline As-cast MgCa0.5Zn0.5 & $0.14 \pm 0.01$ & $156.0 \pm 47.8$ & $87.0 \pm 31.2$ & $0.31 \pm 0.02$ \\
\hline
\end{tabular}

On the other hand, the corrosion behavior and thus corrosion rates of both tested materials are affected by non-uniform corrosion. Non-uniform corrosion is typical for magnesium alloys because all alloying elements or impurities are always more noble than magnesium matrix. The determination of corrosion rate from potentiodynamic curves is difficult due to the complicated extrapolation of Tafel slopes because the obtained curves are significantly rounded. For this reason, the volumetric method was applied. This method allows measuring of hydrogen released thanks to the cathodic reaction. Generally, the cathodic polarization curves of magnesium alloys represent the cathodic hydrogen evolution through water reduction. Obtained results are shown in Tab. 4. 
These results are different from the electrochemical ones. The larger surface, exposed to a corrosive me- dium, can be one of the reasons. The chloride mechanism could take place over the larger surface and this mechanism is described by the equations (3) and (4).

Tab. 4 The results of the volumetric method measured for as-cast alloy

\begin{tabular}{|c|c|c|c|c|c|c|c|c|c|c|}
\hline Time $(\mathrm{min})$ & 30 & 60 & 90 & 120 & 150 & 180 & 210 & 240 & 270 & 300 \\
\hline $\begin{array}{c}\text { Volume of re- } \\
\text { leased } \mathrm{H}_{2}(\mathrm{l})\end{array}$ & $\begin{array}{c}0.000 \\
2\end{array}$ & 0.0003 & 0.0005 & 0.0007 & 0.0009 & 0.0011 & 0.0013 & 0.0015 & 0.0017 & 0.0019 \\
\hline $\begin{array}{c}\text { Corrosion } \\
\text { rate }\left(\mathrm{mm} \cdot \mathrm{a}^{-1}\right)\end{array}$ & 2.84 & 2.84 & 3.16 & 3.32 & 3.41 & 3.48 & 3.52 & 3.55 & 3.53 & 3.60 \\
\hline
\end{tabular}

$$
\begin{gathered}
\mathrm{Mg}(\mathrm{s})+2 \mathrm{Cl}^{-}(\mathrm{aq}) \leftrightarrow \mathrm{MgCl}_{2}(\mathrm{~s})+2 \mathrm{e}^{-} \\
\mathrm{Mg}(\mathrm{OH})_{2}(\mathrm{~s})+2 \mathrm{Cl}^{-}(\mathrm{aq}) \leftrightarrow \mathrm{MgCl}_{2}(\mathrm{~s})+2 \mathrm{OH}^{-}(\mathrm{aq})
\end{gathered}
$$

Another important effect, influencing the different corrosion rates between volumetric and electrochemical methods, is the peeling of the exposed surface resulting in higher occurrence of anodic and cathodic areas. This phenomenon leads to the increase of corrosion rate and worse prediction of corrosion course. The possibility is also the quantity of exchanged electrons. In the case of electrochemical reaction, it is simple to consider only two electrons while for volumetric method, it is necessary to involve the reaction between cation $\mathrm{Mg}^{+}$and water [26]. This causes the inaccuracies within electrochemical measurements because they describe only a part of the corrosion process. For this reason, the volumetric method corresponds to the real situation. Thus, our results are different from published works $[6,18,1927]$. However, it is impossible to compare our results with other authors because the experimental set-up and mediums are different.

\section{Conclusion}

In this paper, the $\mathrm{MgCa0} .5 \mathrm{Zn} 0.5$ (in wt. \%) was prepared by casting and microstructure, mechanical properties and corrosion resistance were studied. It was found that secondary phases $-\mathrm{Mg}_{2} \mathrm{Ca}$ and $\mathrm{Ca}_{2} \mathrm{Mg}_{6} \mathrm{Zn}_{3}$ formed in small amount and they primarily crystallized along the grain boundaries. Its existence caused worse tensile properties and poor ductility. On the other hand, the mechanical properties in pressure were much better with values: $278 \pm 15 \mathrm{MPa}$ for compressive strength, $110 \pm 17 \mathrm{MPa}$ for yield strength and the relative deformation was $21 \pm 2 \%$. The obtained corrosion rate was lower for as-cast alloy than for pure magnesium suggesting better corrosion resistance of $\mathrm{MgCa} 0.5 \mathrm{Zn} 0.5$. Alloying elements (Ca, $\mathrm{Zn})$ improve the corrosion behavior of magnesium alloys, but there is non-uniform corrosion caused by the galvanic corrosion due to potential difference. The corrosion of studied alloy was supported by the releasing of hydrogen.

\section{Acknowledgement}

This work was supported from the grant of Specific university research - grant No

\section{A2_FCHT_2020_066} A1_FCHT_2020_003.

\section{and}

No

\section{References}

[1] WANG, J.-L., XU, J.-K., HOPKINS, C., CHOW, D. H.-K. AND QIN, L. (2020). Biodegradable Magnesium-Based Implants in Orthopedics-A General Review and Perspectives. In: Advanced Science, Vol. 7, No. 8, pp. 1902443. 2198-3844

[2] VIRTANEN, S. (2011). Biodegradable Mg and Mg alloys: Corrosion and biocompatibility. In: Materials Science and Engineering: B, Vol. 176, No. 20, pp. 1600-1608. 0921-5107

[3] XU, Z., SMITH, C., CHEN, S. AND SANKAR, J. (2011). Development and microstructural characterizations of $\mathrm{Mg}-\mathrm{Zn}-$ $\mathrm{Ca}$ alloys for biomedical applications. In: Materials Science and Engineering: B, Vol. 176, No. 20, pp. 1660-1665. 0921-5107

[4] CASTELlANI, C., LINDTNER, R. A., HAUSBRANDT, P., TSCHEGG, E., STANZL-TSCHEGG, S. E., ZANONI, G., BECK, S. AND WEINBERG, A.-M. (2011). Bone-implant interface strength and osseointegration: Biodegradable magnesium alloy versus standard titanium control. In: Acta Biomaterialia, Vol. 7, No. 1, pp. 432-440. 17427061

[5] XIN, Y., HU, T. AND CHU, P. K. (2011). In vitro studies of biomedical magnesium alloys in a simulated physiological environment: A review. In: Acta Biomaterialia, Vol. 7, No. 4, pp. 1452-1459. 1742-7061

[6] DU, H., WEI, Z., LIU, X. AND ZHANG, E. (2011). Effects of $\mathrm{Zn}$ on the microstructure, mechanical property and bio-corrosion property of $\mathrm{Mg}-3 \mathrm{Ca}$ alloys for biomedical application. In: Materials Chemistry and Physics, Vol. 125, No. 3, pp. 568-575. 0254-0584 
[7] STAIGER, M. P., PIETAK, A. M., HUADMAI, J. AND DIAS, G. (2006). Magnesium and its alloys as orthopedic biomaterials: A review. In: Biomaterials, Vol. 27, No. 9, pp. 1728-1734. 0142-9612

[8] DATTA, M. K., CHOU, D.-T., HONG, D., SAHA, P., CHUNG, S. J., LEE, B., SIRINTERLIKCI, A., RAMANATHAN, M., ROY, A. AND KUMTA, P. N. (2011). Structure and thermal stability of biodegradable $\mathrm{Mg}-\mathrm{Zn}-\mathrm{Ca}$ based amorphous alloys synthesized by mechanical alloying. In: Materials Science and Engineering: B, Vol. 176, No. 20, pp. 1637-1643. 0921-5107

[9] PAPILLON, J., SALERO, P., MERCIER, F., FABRÈGUE, D. AND MAIRE, É. (2019). Compressive deformation behavior of dendritic $\mathrm{Mg}-\mathrm{Ca}(-\mathrm{Zn})$ alloys at high temperature. In: Materials Science and Engineering: A, Vol. 763, No. pp. 138180. 0921-5093

[10] ZHANG, B., WANG, Y., GENG, L. AND LU, C. (2012). Effects of calcium on texture and mechanical properties of hot-extruded $\mathrm{Mg}-\mathrm{Zn}-\mathrm{Ca}$ alloys. In: Materials Science and Engineering: A, Vol. 539, No. pp. 56-60. 09215093

[11] BAKHSHESHI-RAD, H. R., IDRIS, M. H., ABDUL-KADIR, M. R., OURDJINI, A., MEDRAJ, M., DAROONPARVAR, M. AND HAMZAH, E. (2014). Mechanical and biocorrosion properties of quaternary $\mathrm{Mg}-\mathrm{Ca}-$ $\mathrm{Mn}-\mathrm{Zn}$ alloys compared with binary $\mathrm{Mg}-\mathrm{Ca}$ alloys. In: Materials \& Design, Vol. 53, No. pp. 283-292. 0261-3069

[12] ATRENS, A., LIU, M. AND ZAINAL ABIDIN, N. I. (2011). Corrosion mechanism applicable to biodegradable magnesium implants. In: Materials Science and Engineering: $B$, Vol. 176, No. 20, pp. 1609-1636. 0921-5107

[13] LI, Z., GU, X., LOU, S. AND ZHENG, Y. (2008). The development of binary $\mathrm{Mg}-\mathrm{Ca}$ alloys for use as biodegradable materials within bone. In: Biomaterials, Vol. 29, No. 10, pp. 13291344. 0142-9612

[14] RAD, H. R. B., IDRIS, M. H., KADIR, M. R. A. AND FARAHANY, S. (2012). Microstructure analysis and corrosion behavior of biodegradable $\mathrm{Mg}-\mathrm{Ca}$ implant alloys. In: Materials \& Design, Vol. 33, No. pp. 88-97. 0261-3069

[15] NIE, J. F. AND MUDDLE, B. C. (1997). Precipitation hardening of $\mathrm{Mg}-\mathrm{Ca}(-\mathrm{Zn})$ alloys.
In: Scripta Materialia, Vol. 37, No. 10, pp. 14751481. 1359-6462

[16] DU, Y. Z., ZHENG, M. Y., XU, C., QIAO, X. G., WU, K., LIU, X. D., WANG, G. J. AND LV, X. Y. (2013). Microstructures and mechanical properties of as-cast and asextruded Mg-4.50Zn-1.13Ca (wt \%) alloys. In: Materials Science and Engineering: A, Vol. 576, No. pp. 6-13. 0921-5093

[17] WIESE, B. (2012). Projektarbeit: Thermodynamische Berechnung des Mg-CaPhasendiagramms. In: Flensburg/Geesthacht: FH Flensburg.

[18] ZANDER, D. AND ZUMDICK, N. A. (2015). Influence of $\mathrm{Ca}$ and $\mathrm{Zn}$ on the microstructure and corrosion of biodegradable $\mathrm{Mg}-\mathrm{Ca}-\mathrm{Zn}$ alloys. In: Corrosion Science, Vol. 93, No. pp. 222-233. 0010-938X

[19] BAKHSHESHI-RAD, H. R., ABDULKADIR, M. R., IDRIS, M. H. AND FARAHANY, S. (2012). Relationship between the corrosion behavior and the thermal characteristics and microstructure of $\mathrm{Mg}-$ 0.5Ca-xZn alloys. In: Corrosion Science, Vol. 64, No. pp. 184-197. 0010-938X

[20] STEPANOV, N. D., YURCHENKO, N. Y., SOKOLOVSKY, V. S., TIKHONOVSKY, M. A. AND SALISHCHEV, G. A. (2015). An AlNbTiVZr0.5 high-entropy alloy combining high specific strength and good ductility. In: Materials Letters, Vol. 161, No. pp. 136-139. 0167-577X

[21] SUN, Y., ZHANG, B., WANG, Y., GENG, L. AND JIAO, X. (2012). Preparation and characterization of a new biomedical $\mathrm{Mg}-\mathrm{Zn}-$ Ca alloy. In: Materials \& Design, Vol. 34, No. pp. 58-64. 0261-3069

[22] CIHOVA, M., MARTINELLI, E., SCHMUTZ, P., MYRISSA, A., SCHÄUBLIN, R., WEINBERG, A. M., UGGOWITZER, P. J. AND LÖFFLER, J. F. (2019). The role of zinc in the biocorrosion behavior of resorbable $\mathrm{Mg}-\mathrm{Zn}-\mathrm{Ca}$ alloys. In: Acta Biomaterialia, Vol. 100, No. pp. 398-414. 1742-7061

[23] WAN, Y., XIONG, G., LUO, H., HE, F., HUANG, Y. AND ZHOU, X. (2008). Preparation and characterization of a new biomedical magnesium-calcium alloy. In: Materials \& Design, Vol. 29, No. 10, pp. 20342037. 0261-3069 
[24] CAIN, T., BLAND, L. G., BIRBILIS, N. AND SCULLY, J. R. (2014). A Compilation of Corrosion Potentials for Magnesium Alloys. In: Corrosion Vol. 70, No. 10, pp. 1043-1051.

[25]NAM, N. D. (2015). Role of Zinc in Enhancing the Corrosion Resistance of Mg5Ca Alloys. In: Journal of The Electrochemical Society, Vol. 163, No. 3, pp. C76-C84. The Electrochemical Society. 0013-4651, 19457111
[26]LOVAŠI, T., PINC, J., VOŇAVKOVÁ, I. (2019). Zinc-based Degradable Biomaterials Limitations and Enhancements. In: Manufacturing Technology, Vol. 19, No. 4, pp. 632-636.

[27]DVORSKÝ, D., KUBÁSEK, J., VOJTĚCH, D. (2017). Characterization of Composite Material with Magnesium Matrix Prepared by Powder Metallurgy. In: Manufacturing Technology, Vol. 17, No. 5, pp. 691-695. 